\title{
Errantes, diferentes, desiguais: em torno de Os emigrantes, de W. G. Sebald
}

\author{
Paulo Cesar Silva de Oliveira ${ }^{1}$
}

\begin{abstract}
Resumo: Este trabalho propõe uma leitura crítica de Os emigrantes, de W. G. Sebald (2002), problematizam as dicotomias estabelecidas na modernidade entre uma promessa de mobilidade contraposta à clausura de um mundo marcado, conforme a acepção de Walter Benjamin, pelo "mal do progresso" inscrito no pesadelo da história. A ficção de Sebald se constrói nas interseções entre memória, documento, história, etnografia e ficção. Seu texto será lido como movimento de passagem que convoca a crítica à análise de uma série discursiva composta por um campo reflexivo em torno das antinomias de uma Europa moderna arrebatada no século XX pelo trauma, pela catástrofe e pela ruína. Neste sentido, Sebald dialoga com formas textuais híbridas que, por meio de uma poética do fragmento, renova o realismo literário, influenciando decisivamente a prosa ficcional contemporânea. Em Sebald, a tematização do mundo arruinado se converte em uma alegoria da era das catástrofes e do destino de sujeitos migrantes. $\mathrm{O}$ artigo discute as implicações teóricas e o alcance deste conjunto de temas e reflexões.
\end{abstract}

Palavras-chave: Ficção contemporânea. História. Memória. Trauma. Realismo. Crítica.

Não serei o poeta de um mundo caduco.

Também não cantarei o mundo futuro.

Estou preso à vida e olho meus companheiros.

Estão taciturnos mas nutrem grandes esperanças.

Entre eles, considero a enorme realidade.

O presente é tão grande, não nos afastemos.

Não nos afastemos muito, vamos de mãos dadas.

Carlos Drummond de Andrade

As relações da literatura com a reflexão crítica da modernidade frequentemente apontam para as contradições entre as promessas do capitalismo global, que nos primórdios de sua expansão mundial foi capitaneado pelos europeus, e a realização de suas juras, especialmente em relação às áreas e populações chamadas periféricas. Tanto na Europa quanto no proclama do Novo Mundo, as modernidades periféricas nomeiam um modo particular de desencanto. No caso brasileiro, a partir da expansão e da dominação colonial

\footnotetext{
${ }^{1}$ Doutor em Letras pela Universidade Federal do Rio de Janeiro e Pós-doutor em Estudos de Literatura pela Universidade Federal Fluminense. Professor Adjunto de Teoria Literária (Departamento de Letras) na Faculdade de Formação de Professores da Universidade do Estado do Rio de Janeiro. Bolsista do PROCIÊNCIA (FAPERJ/UERJ) e Bolsista de Produtividade em Pesquisa do CNPq. Rio de Janeiro, Brasil. E-mail: paulo.centrorio@uol.com.br. i http://orcid.org/0000-0002-1825-0097.
} 
marítima portuguesa formou-se uma sociedade multirracial, multiétnica, porém, à força de extermínios, sequestros, escravização e exploração dos negros vindos de África, dos índios e de pobres de toda a sorte, enredados em um sistema de leis segregador. Apesar de datas emblemáticas, como o 13 de maio de 1888, a esperança de uma modernidade que fecharia ciclos de horror e barbárie é um horizonte ainda hoje longínquo. Nada até agora dito é novidade. O percurso, embora complexo, é nosso conhecido e não nos alongaremos nele. Os termos com que a modernidade estabeleceu as ideias de mobilidade, progresso e redenção jamais se materializaram para a grande maioria de sujeitos enclausurados que desmentem as pretensas emancipação e luminosidade modernas. No caso da arte moderna, podemos dizer que ela tem seu apogeu e declínio a partir dos movimentos de vanguarda do século XX - no caso do Brasil, após a consolidação dos fenômenos artísticos abrigados sob o manto do Modernismo. No campo da crítica, não podemos esquecer a década de 1910, que nos legou o Formalismo Russo, cuja mirada crítica renovou o campo das discussões sobre a especificidade do literário e formou uma geração de teóricos pouco afeitos à leitura impressionista da arte em prol de uma crítica do texto e dos processos de estranhamento emanados de sua estrutura. $\mathrm{O}$ século XX seria decisivo à formação de novas categorias reflexivas na área das Humanidades, especialmente em relação ao campo literário.

A abrangência das relações entre arte e sociedade pressupõe a mirada histórica. Essas relações não configuram sistemas de saber estanques ou conjuntos de ideias coerentes, já que não rumam a uma síntese: ao contrário, elas estruturam um feixe de relações controversas, dinâmicas, por vezes paradoxais na formação de certo pensamento da modernidade ora constituído por uma globalização de fábula ora acossado pela globalização de fato, traduzida como globalização da perversidade, na esteira do pensamento do geógrafo Milton Santos (2001). Esses paradoxos surtem efeitos sobre as artes e no campo literário tal problematização assume papel decisivo na leitura de um grupo de autores e narrativas de línguas, culturas e geografias diversas. Uma dessas narrativas nos guiará, particularmente, pelos meandros de algumas antinomias modernas.

Em Os emigrantes (1993), o escritor alemão Winfried Georg Maximillian Sebald (W. G. Sebald) encerrava a primeira parte da obra referindo-se a uma notícia encontrada em um jornal de Zurique. O periódico era publicado na cidade de Lausanne e trazia uma informação sobre o caso do guia de montanhas Johannes Naegeli. O leitor, àquele momento da leitura do romance, já identificará quem é e qual a importância desta personagem na trama. O jornal 
dizia que os restos mortais do guia desaparecido desde 1914 tinham sido devolvidos "depois de 72 anos pela geleira de Obeaar" e o episódio servirá para que o narrador conclua seu relato: “Assim, pois, retornam os mortos. Às vezes depois de mais de sete décadas eles saem do gelo e ficam deitados na beira da morena, um montinho de ossos polidos e um par de botas com cravos" (SEBALD, 2002, p. 28).

Por meio de uma visão emblemática da história e da própria modernidade perversa que se descortinava no nascente século XX, disseminando-se ao longo de toda a sua primeira metade, Sebald cria formas alegóricas de compreensão da história através de uma sequência contundente de movimentos traumáticos que pontuam o período e marcam até hoje várias gerações atropeladas pelo lado mais sombrio do progresso, resultante da quebra da promessa moderna de emancipação e liberdade cujo contraponto seria o predomínio do pesadelo da barbárie e das catástrofes. Não sem razão, a imagem de um pesadelo da história viria a compor um conjunto complexo de questões disseminadas em um texto fundamental para o pensamento do século XX: as inacabadas teses "Sobre o conceito de história", de Walter Benjamin (1985).

Neste trabalho, o último antes do suicídio do pensador, em 27 de setembro de 1940, na localidade de Port Bou, região da Catalunha, Walter Benjamin (1985, p. 223) defendia a figura do cronista como o grande fabulador da modernidade, alguém capaz de narraras experiências, os fatos, sem distingui-los entre grandes e pequenos, já que "leva em conta a verdade de que nada do que um dia aconteceu pode ser considerado perdido para a história". Para Benjamin, somente pela apropriação total do passado é que a humanidade poderia alcançar a redenção. Obviamente, esse olhar redentor será devedor de algumas escolhas pautadas pela empatia com os desfavorecidos, como entendia e propunha Benjamin, sendo este o papel do verdadeiro historiador. Ao estabelecer a opção ética pelos despossuídos, o investigador da história terá condições de compreender com mais clareza que os monumentos de cultura são também monumentos de barbárie, pois aos vencidos resta atuar na condição de coadjuvantes de sua própria experiência. Por isso, o historiador revolucionário tem como missão "escovar a história a contrapelo", com a consciência "de fazer explodir o continuum da história", o que é uma característica das "classes revolucionárias no momento da ação" (BENJAMIN, 1985, p. 225).

Porque não podemos trazer de volta o passado na integralidade do que ele realmente foi, entretanto, é possível vislumbrar uma reminiscência que surge em momentos de perigo. 
Daí a importância da memória, que pode manter a integridade dos vencidos, seja pela lembrança ou pela denúncia. Sem a memória, teríamos diante de nós apenas uma ética precária, já que as injustiças históricas não poderão jamais ser reparadas, pois isso dependeria de uma alteração impossível nos eventos do passado. A reminiscência teria o poder, segundo Benjamin, de recuperar os processos históricos que ratificam a injustiça e consolidam a barbárie para em seguida desconstruí-los; e para isso é preciso dar sentido no presente às narrativas daqueles indivíduos e grupos descartados do arquivo oficial, mas que precisam ser resgatados do limbo da história. Como os vencidos estão sempre do lado mais fraco, caberia ao verdadeiro revolucionário a tarefa de auxiliá-los nesta tarefa. Os revolucionários não são uma categoria, nem um grupo especial de consciência ou de guias, mas podem preencher uma lacuna fundamental, operando na qualidade de intelectuais com meios de fazer girar a roda da história em favor da recuperação da memória e da história dos derrotados. Neste sentido, o historiador materialista é aquele que, segundo Benjamin reúne as condições para promover o "retorno dos mortos", conforme ficcionalizado por Sebald, e isso não seria uma espécie de reparação, mas um modo de atuação política da memória visando a um aprendizado que nos impele a seguir em frente, fazendo justiça aos que foram deixados para trás ou fora dos discursos triunfantes do progresso. As propostas de Benjamin conferem uma dimensão política a seu pensamento e aqui gostaríamos de acentuá-las, no jogo da leitura com o romance Os emigrantes.

O romance de Sebald se divide em quatro partes, cada uma focalizando processos da memória de um narrador que no presente do relato articula a história de sujeitos que tiveram uma participação fundamental em sua vida e em sua visão de mundo aponta para o cuidado com os resquícios, com os fragmentos, com os conhecimentos grandes e pequenos que compõem o mosaico dos sonhos e pesadelos do progresso, como afirmara Benjamin. Essa mesma modernidade que permite ao narrador e a seus quatro personagens se deslocarem intensamente entre regiões, países, línguas, por outro lado, é contraposta à clausura experimentada pelas vítimas da barbárie, principalmente nos anos compreendidos entre 1914 e 1945 - respectivamente, início da Primeira e fim da Segunda Guerra na Europa. O narrador fala a partir de um presente da narrativa no qual os acontecimentos são recuperados por meio de reminiscências. Para Reyes Mate (2011, p. 52-53), Benjamin acreditava que "o mal do progresso é o esquecimento" que quando "volta as costas ao passado se torna suicida". Entre o progresso pensado por Benjamin e o dos tempos de globalização, obviamente, há um hiato 
histórico. Quanto a isso, Mate defende que aquele tempo pensado pelo filósofo havia sido erguido sobre os ombros dos pobres, dos escravizados e despossuídos, enquanto que o mercado de hoje entende que os pobres já não são tão essenciais, pois quem não participa da cadeia de produção de riqueza é considerado peso morto, despojo da modernidade líquida, apenas mais um objeto descartável na pilha de dejetos das comunidades hodiernas.

Os sujeitos ficcionalizados por Sebald sãopor vezes suicidas e/ou criaturas enclausuradas. São personae fatigadas da lida vivendo em um mundo onde não encontram lugar, como a personagem Paul Bereyter, figura central da segunda parte do romance (cada uma das partes leva o nome da personagem-alvo), um meio-judeu que aos poucos se vê no ostracismo imposto pelo regime nazista que se agigantava e tomaria dimensões escabrosas até a "devastação", embrionariamente ficcionalizada por Sebald no momento em que Tekla, a mãe de Bereyter, atriz do Teatro Municipal de Nuremberg, fora impedida de frequentar o Café de Yverdon, pelo motivo de o pai de Bereyter ser um meio-judeu. Essa passagem se conclui bela e amargamente com o relato de uma testemunha (Madame Landau)sobre um momento crucial do passado de Paul Bereyter:

[...] não me espanta nada que o senhor não soubesse das maldades e mesquinharias a que uma família como os Bereyter estava exposta num buraco como S. era então, e continua sendo apesar do assim chamado progresso; não me espanta nada, pois isso faz parte da lógica de toda essa história (SEBALD, 2002, p. 54).

Em outro exemplo, na primeira parte do romance, a história da família do Dr. Henry Selwyn fornece mais elementos para que o leitor reconstrua os sentidos dessa "lógica" apontada por Madame Landau. A família de Selwyn, oriunda de uma aldeia lituana, viajou em uma carroça, no final do outono de 1899, para Grodno, cidade do interior da Bielorrússia. As imagens daquela viagem são recuperadas por Sebald no momento em que a voz do professor domina a narrativa, sem qualquer aviso ao leitor, pela estratégia de o autor privilegiar os discursos indireto e indireto livre, fazendo com que as reminiscências de Selwyn se confundam com as lembranças do narrador supostamente identificado com Sebald: 
[...] vejo o lombo dos cavalos, a terra castanha e ampla, os gansos no lamaçal das granjas com os pescoços esticados e a sala de espera da estação de Grodno com o aquecedor no meio da sala, protegido por grades e superaquecido, e as famílias de emigrantes instaladas ao redor dele. Vejo os fios de telégrafo subindo e descendo diante das janelas do trem, vejo as fachadas das casas de Riga, o navio no porto e o canto escuro do convés onde, com todas as limitações da circunstância, procuramos nos acomodar em alto-mar; lembro o rastro de fumaça, o horizonte cinzento, o subir e o descer do navio, o medo e a esperança que todos sentíamos; revivo tudo isso, disse-me o dr. Selwyn, como se fosse ontem.

O jogo da memória estabelece uma simbiose entre o relato comandado pelo Sebald narrador e aquilo que ele nos entrega a respeito do Dr. Selwyn. A memória que tenta recuperar um dado da experiência, ainda que a leiamos sob o ponto de vista do documento histórico - como no caso dos arquivos pessoais, das documentações e dos diários, das cartas, dos bilhetes e demais vestígios que analisamos como produtos da experiência - nos chega através de relatos passíveis de questionamentos, por exemplo, dos poderes da interpretação, um trabalho que Benjamin (1985) atribuiu ao cronista, cujo papel seria o de narrar acontecimentos pequenos e grandes sem distingui-los. Essa concepção é importante, pois pressupõe que a atuação do cronista permite um resgate mais efetivo do evento histórico e o historiador mais afeito ao materialismo histórico, ao contrário, acabaria deixando de lado quando privilegia os grandes relatos, relegando a um segundo plano os pequenos eventosruína que compõem um quadro mais sincero ou pelo menos mais abrangente do passado. Recuperá-lo em sua totalidade e em cada um de seus momentos só seria possível, segundo Benjamin (1985, p. 223), "para a humanidade redimida" em que "cada momento vivido transforma-se numa citation à l'ordre du jour - e esse dia é justamente o dia do juízo final'. A essa frase, que fecha a Tese 3, de "Sobre o conceito de história", sucede a epígrafe retirada de um texto de Georg Wilhelm Friedrich Hegel, de 1807: "Lutai primeiro pela alimentação e pelo vestuário, e em seguida o reino de Deus virá por si mesmo" (BENJAMIN, 1985, p. 223). Como se nota, a citação se ancora no conceito de luta de classes; indo além, ela recusa a ideia de que as coisas do espírito devam ser representadas como despojos atribuídos aos vencedores da história. Por isso, a imagem do passado passa por nós velozmente e só se deixa apanhar em um instante de perigo, quando o historiador-cronista divisa no presente transformado o efeito daquela imagem do passado. Isso não significa dizer que conheceremos o passado como ele 


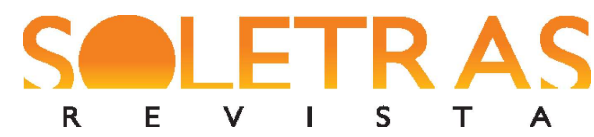

N. 38 - 2019.2 - PAULO CESAR SILVA DE OLIVEIRA

realmente foi (BENJAMIN, 1985, Tese 6), mas sim como algo arrancado do conformismo por um salvador que nos chega como aquele que derrotará o Anticristo.

A função messiânica em Benjamin se revela na noção de "salvação" (GAGNEBIN, 2018, p. 72), em que se fundem teologia e marxismo: “A ideia da libertação necessária da classe dominada une-se à doutrina judaica da redenção". Hoje, quando os conceitos de salvação fundados na teologia adquirem caráter extremamente conservador - nem redenção para os despossuídos nem opção clara dos discursos hegemônicos por eles - pode parecer que a tese de Benjamin esteja momentaneamente nocauteada por uma espécie de revés da consciência crítico-politica descompromissada com o destino dos sujeitos subalternizados. Em sua época, Benjamin também vivenciou as ameaças poderosas do nazismo e dos fascismos que foram se disseminando por grande parte da Europa. Seu suicídio foi motivado pelo pavor de sucumbir à catástrofe e ao decorrente sofrimento. De fato, os temores de Benjamin se concretizaram em grande parte do continente europeu e seu ápice monstruoso seria a sistemática perseguição e extermínio dos judeus.

Neste sentido, qualquer processo histórico é devedor dos relatos da memória e dos testemunhos e é ainda Benjamin quem pode nos fornecer alguns parâmetros de reflexão importantes. Reyes Mate nos recorda de que em um texto bem anterior às teses sobre o conceito de história, o "Fragmento teológico-político" (2019), Benjamin distinguia uma ordem profana (baseada na felicidade dos vivos) de uma ordem messiânica. Esta levaria em conta a redenção e a felicidade dos mortos. As duas ordens são representadas por flechas que se movem paralelamente, mas em sentidos opostos. Felicidade e redenção seriam termos essenciais, pois nelas o destino dos fracassados é o fundamento da felicidade dos vivos. Parafraseando Hegel, Benjamin dirá que não mais pisotearíamos as flores no chão da história, ao contrário, nossa tarefa consistiria em relacionar a "vida frustrada dos mortos com o interesse dos vivos", já que "se os mortos não importam, então, a felicidade não é coisa do homem, mas do sobrevivente" (REYES MATE, 2011, p. 30).

Os emigrantes de Sebald foram os sobreviventes da história que no presente do relato estão mortos. São as testemunhas que cumprem a tarefa de preservar sua memória, preenchendo as lacunas entre o tempo histórico vivido e o tempo presente, conferindo ao leitor a tarefa de juntar os cacos da história recuperados a partir de vestígios deixados pelo caminho, ao longo da história: o texto, a escrita como produto da função autor se vale da figura do narrador no processo de jogo ficcional promovido por Sebald. Somos nós, seus 
leitores, que temos a responsabilidade de nos desviar das flores do caminho de modo a não pisá-las. É através da análise crítico-teórica que conseguiremos prever o momento da chegada de um tempo messiânico no qual a redenção se apresenta como elemento fundamental das esferas do bem e da justiça. A redenção cintilará na noite escura da história a partir do momento em que priorizarmos os acontecimentos menores, ainda que eles sejam "cacos da história" (GAGNEBIN, 2018) a serem reunidos em uma espécie de mosaico impossível, necessário e urgente.

Não sem razão, W. G. Sebald privilegia em sua ficção a representação de sujeitos subalternizados, como os migrantes, os desenraizados que circularam e circulam pelas regiões, ora mais pobres ora mais nobres do capital e da história do século $\mathrm{XX}$, os quais invariavelmente tomam o destino em suas mãos, por exemplo, quando recorrem à radicalidade do suicídio. Para o narrador de Sebald, a tarefa que se impõe é a de recuperar os fragmentos de vida daqueles sujeitos adernados. Ele quer recuperar alguns pedaços dispersos da história que (se) foi e cuja reapropriação somente será possível pela recordação (reminiscência) expressa por um relato híbrido, misto de história, crônica e invenção.

Em "Paul Bereyter", segunda parte da narrativa de Os emigrantes, o elemento que dispara o mecanismo da rememoração é o obituário de um jornal local da cidadezinha sinalizada pela inicial S.e que traz a notícia do suicídio de Paul Bereyter, professor na escola primária onde estudara o narrador, que decide conjurar suas lembranças daquele homem e de seu passado para "descobrir uma história" que desconhecia (SEBALD, 2002, p. 34). É neste sentido que o cronista se confunde com o historiador e o memorialista; os três são investidos da tarefa de juntar os pedaços de uma história jamais concluída por meio de um texto que, mesmo sem descartar o rigor da busca pelos fatos históricos ou a utilização dos documentos à disposição, no entanto, opta pela invenção, conferindo poderes inusitados ao relato, já que permite ao leitor entrar em contato com imagens pulsantes, sejam elas de caráter poético, político ou social e através de um texto melancólico, porém vibrante, essencial à construção alegórica de um mundo trágico fixado pela prosa de Sebald. Daí a referência a momentos que expressam o conluio entre ficção, memória e história no relato do cronista:

[...] tentei imaginar como ele tinha vivido no grande apartamento do andar de cima da velha casa de Lerchenmüller, que antigamente ficava onde agora fica o prédio de apartamentos e era cercada pelos canteiros verdes e 


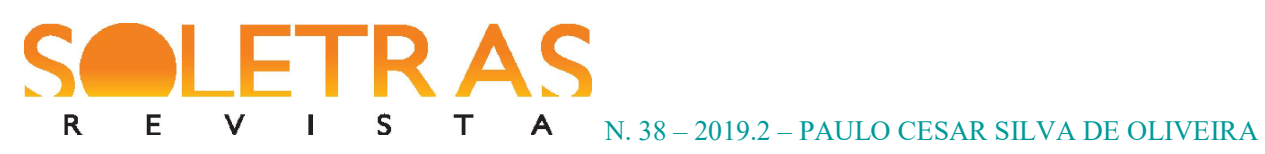

coloridos de verduras e flores que em muitas tardes contaram com a dedicação dele (SEBALD, 2002, p. 35).

A rememoração de pequenos fatos, de lugares, de eventos aparentemente prosaicos ou insignificantes vai construindo pouco a pouco um universo no qual o morto surge para nós redimido, seja pelas catástrofes a que sobreviveu - Bereyter, por exemplo, fora impedido de exercer a profissão de professor pelo nazismo; mais tarde, foi obrigado a emigrar; enamorouse de escritores suicidas; cortejou o abismo nos momentos de perigo registrados na história do século XX - ou pela decisão de se suicidar. A consciência da inadequação acompanha Bereyter por toda a vida, marcando sua subjetividade de forma indelével. Para os nazistas, sua herança genética o tornava um híbrido indesejado, somente três quartos alemão, mas para Bereyter, o que o fez voltar em 1939 ao ambiente ameaçador da Alemanha nazista, à cidade de S., mais precisamente, era justamente o contrário: sua consciência de ser “fundamentalmente um alemão" (SEBALD, 2002, p. 61).

Esse entendimento doloroso, de que em um mundo de barbárie os sujeitos se chocam intensamente com a ideia de mobilidade trazida pela modernidade de fábula, explica a solidariedade de Bereyter com os inadequados. No plano alegórico, a imagem do trem é uma obsessão da personagem. Para Bereyter, o trem significava a representação de um mundo marcado pela morte - os trens transportavam preferencialmente as vítimas do Holocausto - e pela promessa de mobilidade, fuga, de movimento rumo à liberdade. Os trens eram "imagem e símbolo da infelicidade alemã de Paul, nos conta Madame Landau" (SEBALD, 2002, p. 66). Quando criança, Bereyter tinha "mania por trens" e fascinava-se vendo "diariamente os trens rolarem do continente para a ilha e da ilha para o continente", o que motivou seu tio a comentar de forma ambígua que um dia o sobrinho "iria acabar na ferrovia" (SEBALD, 2002, p. 66), o que se consuma com o suicídio de Bereyter na ferrovia. A reconstrução dos motivos que levaram Bereyter ao suicídio é precária e mostra os poderes da ficção, por um lado, e seus limites, de outro. A memória e o relato histórico só podem ser libertados pela ficção/invenção, como nos conta o narrador:

Na minha fantasia, ele havia tirado os óculos, colocando-os a do a lado, sobre o cascalho. Os aros brilhantes de aço, os dormentes, o bosquezinho de 
pinheiros na encosta da cidade velha, e a curva das montanhas que lhe era tão familiar, tinham-se diluído diante de seus olhos míopes, apagando-se na penumbra (SEBALD, 2002, p. 35, grifo nosso).

A questão da experiência e o problema das relações entre relato histórico, memória e narrativa ficcional nos remetem à discussão sobre a verdade e a recuperação do passado. Situar o relato memorialístico e o testemunho no campo da experiência concreta, no que tange à verdade histórica, requer uma perspectiva aberta: entende-se que para atingir o objetivo de uma história redentora,o ponto de partida crucial seria o de pensar as margens e as exterioridades na formação de um imaginário do mundo moderno. No caso do campo literário, seu discurso privilegiado, porque formado pela multiplicidade de saberes (a mathesis), nos leva ao termo "literatura de passagem", cunhado por Lucia Helena, conceitochave que ela retira da leitura de Benjamin sobre as passagens de Paris. Para Helena (2012, p. 63), a ideia de passagem revela novos horizontes de compreensão da questão das fronteiras, já que suplementa o radicalismo da ruptura e permite o contágio entre passado e presente, entre antigo e novo em uma convivência longe de ser harmônica, mas sim reveladora das potencialidades advindas da tensão entre termos de uma complexa equação. Helena advoga o hibridismo como modo de ler o mundo, já que as fronteiras planetárias em tempos de globalização são contamináveis. São fenômenos intensamente problematizados por um determinado grupo de autores e obras marcadas por processos de contaminação e disseminação: textos remetendo a outros textos que se comunicam por meio de diferentes suportes, estruturados como palimpsestos em um processo intertextual e referencial intenso, pelo qual "a literatura e os fragmentos que orientam sua composição revelam-se passagens" (HELENA, 2012, p. 67). Esse modo de compreensão do literário, aliado à proposta de Helena, de ler esse tipo de literatura pelo viés do desassossego, também se revela como estratégia de leitura crítica bastante produtiva de textos como os de Sebald.

O desassossego é um conceito que se origina na poética de Fernando Pessoa. Para Helena, o desassossego já podia ser percebido na obra dos tragediógrafos gregos antigos e modernamente na escrita de um número expressivo de autores que compuseram o campo literário e intelectual do século XX. Dentre estes, W. G. Sebald pode sem dúvida ser incluído no rol de escritores do desassossego contemporâneo. Conforme Helena (2016, p. 67), 
[...] o eu das ficções do desassossego está sempre na iminência do provisório, do indefinido, da transição e da metamorfose, no traçado das preocupações de ordem existencial, tanto no plano pessoal, como no plano contextual da vivência mundana e fragmentária do eu.

Nosso desassossego contemporâneo se expressa pelo sentimento de deriva dos sujeitos em um mundo líquido caracterizado pela volatilidade do capital, pela violência desenfreada, pelos imperativos do mercado e por uma mundanidade estéril disseminada nos campos sociais, políticos, econômicos e artísticos. O homem angustiado seria representativo da modernidade e sua incessante e intensa experiência deambulatória, na qual são percebidos os elementos do desassossego, desequilibram a segurança da paisagem existencial e social. Nesta compreensão do mundo moderno, o sujeito é visto como alguém que deveria transitar livremente pelos espaços diversos do globo. Essa mobilidade, aparentemente, deveria revelar o triunfo da modernidade, apontando para um futuro promissor, pleno de possibilidades de encontro com a felicidade e com o bem-estar comum. Nesta utopia, os sujeitos gozariam da plenitude do pertencimento a um lugar no mundo. Como vimos, entretanto, a promessa moderna frequentemente se converte em pesadelo moderno.

A velocidade que abreviaria nossos deslocamentos, liberando nosso tempo para o lúdico, ainda aliviaria o fardo do trabalho, levando-nos a um estado ideal de segurança e felicidade, acabou se tornando um instrumento auxiliar dos processos de controle. No caso dos conflitos bélicos que marcaram o século $\mathrm{XX}$, o avião se transformaria em máquina letal; os trens, que deveriam encurtar as fronteiras espaciais e temporais do mundo, tornaram-se aparelhos de terror, símbolos do extermínio de populações inteiras, como no caso dos judeus, gays e ciganos. Sintomaticamente, o suicídio de Paul Bereyter, em Os emigrantes, se consuma nos trilhos da ferrovia de sua cidade de origem, S. A profecia de seu tio resolve a ambiguidade da frase que apontava a estação de trem como o destino final de Bereyter, entretanto não como um viajante que goza da promessa moderna de mobilidade, mas como vítima preferencial de um tempo-espaço de clausura e desesperança.

Os homens desassossegados representados por Sebald sabem que viver é perigoso e que o mundo da promessa não lhes deu escolhas, ao menos as pressupostas e defendidas na carta de intenções da modernidade. Alijados dos processos mundanos, eles representam os 
sujeitos atingidos pela instrumentalidade do progresso, da qual Benjamin também foi uma vítima. Os movimentos obscuros e contraditórios da modernidade assumiram protagonismo ao longo do século XX e compuseram um panorama da claudicante modernidade da promessa convertida em modernidade de pesadelo hoje transmudada em globalização da perversidade (SANTOS, 2002) $)^{2}$. Para Benjamin, o progresso é cúmplice da barbárie a partir do momento em que, de forma suicida, virou as costas para o passado e elegeu o esquecimento como um dos pilares de seu programa filosófico. À tentativa desesperada de lembrar, de recuperar o passado estilhaçado, o que vemos é uma sombra do esquecimento ora como forma de sobrevivência social ou psíquica dos indivíduos em meio a uma excessiva carga traumática ora como conteúdo programático de uma história que se fez e faz pisoteando as flores da estrada, no apagamento do outro como sujeito de si e da (própria) história.

Uma referência ao pensamento da clausura aparece de forma clara na Tese 10, onde Benjamin mostra que as regras do claustro religioso visavam a desviar os monges das atrações do mundo. Para o pensador, precisamos "arrancar a política das malhas do mundo profano", depois de consumada a traição dos políticos convertidos ao fascismo - lembremos de que estamos falando de um momento histórico vivido por Benjamin, que sofreu as consequências da ascensão e consolidação dos regimes totalitários na Europa, que passaram a defender uma “obtusa fé no progresso" e na "subordinação servil a um aparelho incontrolável" chamado Estado (BENJAMIN, 1985, p. 227). Dessa maneira, o filósofo entendeu que o progresso estaria cada vez mais circunscrito ao poder e nossa tarefa seria a de combater essa ideia conservadora de progresso pela recusa do conformismo que aprisiona a tradição. Quanto a isso, a classe revolucionária e vingadora deveria ser composta majoritariamente pelos oprimidos, cuja luta libertaria a legião de derrotados e humilhados no progresso instrumental. Na Tese 15, Benjamin (1985, p. 230) dirá que é papel das classes revolucionárias firmar uma consciência da mudança que faça explodir o continuum da história.

\footnotetext{
${ }^{2}$ Para Milton Santos (2002), há na contemporaneidade três formas de se pensar o mundo globalizado: como fábula, perversidade e possibilidade. $\mathrm{O}$ mundo de hoje, tal como querem nos fazer crer, seria representado pela globalização de fábula, caracterizada pela existência de uma aldeia global que une de forma simétrica as vidas humanas na maior parte do planeta, contrapondo-se à globalização perversa, mais próxima da realidade do mundo: imensas massas de desempregados, migrantes, vítimas das guerras, trabalhadores expostos a baixos salários e ao subemprego; mundo onde as conquistas sociais e econômicas estão constantemente ameaçadas. Mas há ainda, de acordo com Santos (2002, p. 29-36), inúmeras possibilidades de se chegar a uma distribuição equânime da riqueza e dos bens simbólicos. Elas seriam dadas pelas condições atuais do capital, marcadas pela concentração de pessoas nas grandes cidades; pelo acesso às tecnologias de informação; e pela democratização dos espaços de discussão e intervenção através dos meios de informação e da técnica. Todos esses elementos seriam indícios da possível emergência de um mundo novo, mais equilibrado e justo. Milton Santos analisou esses fenômenos, abrigando-os em uma proposta: por uma outra globalização, uma globalização possível.
} 


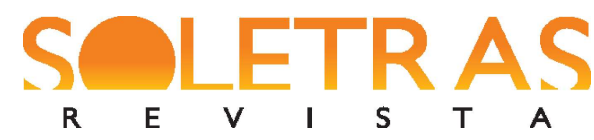

N. 38 - 2019.2 - PAULO CESAR SILVA DE OLIVEIRA

Para nossa leitura de Sebald, a Tese 17 lança provocações instigantes. A Tese trata do historicismo e da historiografia. Contudo, antes de prosseguirmos, precisamos fazer um desvio. Conforme informa Reyes Mate (2011, p. 355), uma das teses de Benjamin não constava nas primeiras traduções do texto para o espanhol nem figurava nas primeiras edições alemãs. Esta tese foi descoberta por Giorgio Agamben em 1981. Tratava-se de um texto datilografado em que Benjamin registrou um breve fragmento como sendo a Tese XVII a (Reyes Mate mantém essa forma grafada). Não se sabe ao certo se este pequeno texto deve ser lido posteriormente à Tese 17, já publicada em outras edições. Cotejando-as, podemos estabelecer leituras produtivas de ambos os materiais.

Em uma passagem familiar aos leitores das Teses, Benjamin (1985, p. 231) propunha o distanciamento entre a historiografia materialista e a história universal. Para ele, a história universal não possui "armação teórica", já que "utiliza a massa dos fatos, para com eles preencher o tempo homogêneo e vazio", enquanto que a historiografia marxista preza pelo princípio construtivo, ou seja, ela percebe haver no passado oprimido uma possibilidade de luta e de incorporação dos eventos eludidos. Isso quer dizer que é factível extrair o máximo de uma época determinada da vida para que a totalidade dos processos históricos seja idealmente a meta ideal a ser atingida. Cabe ao historiador atarefa de reconstruir o passado e quanto a isso a memória possui papel decisivo, já que por meio dela exprime-se uma concepção de universalidade como busca incessante pela singularidade dos fatos do mundo da vida. $\mathrm{O}$ método historiográfico materialista é capaz de captar em uma determinada época o curso homogêneo da história, pois uma determinada vida e uma determinada obra, em um tempo dado, surpreendem a lógica da universalidade histórica em prol de uma visão mais nutritiva,a do fruto que guarda em seu interior o tempo e suas sementes preciosas.

A imagem do fruto nutritivo lembra que o conhecimento não reside em um objeto passivo, ao contrário, pulsa como fonte geradora de vida e transformação já que, ao germinar, a semente que carrega faz eclodir o tempo passado no agora. A memória, como se verá, propicia essa germinação com mais propriedade do que o historicismo. Benjamin acentua que o princípio da construção é a base do trabalho do historiador materialista. Por isso, a mônada, conceito tomado de empréstimo ao filósofo alemão Gottfried Wilhelm Leibniz (1646-1716),é para Benjamin (1985, p. 231) a possibilidade de algo tão singular ou pequeno poder representar o todo: "O materialista histórico só se aproxima de um objeto histórico quando o confronta como mônada”. Para Leibniz, a mônada é única e indivisível, porém deve ser 
compreendida como uma espécie de unidade originária responsável pela composição dos corpos. O sentido universal não demite o dado particular, único, que cada evento carrega em si como possibilidade de se pensar um presente saturado de agoras. Para Benjamin (apud MATE, 2011, p. 355), “a verdade é que não há um só instante que não traga consigo a sua oportunidade revolucionária”. Nesta passagem citada da Tese XVIIa, Reyes Mate afirma que o objetivo de Benjamin é "aquilatar o significado do tempo pleno ou messiânico, uma árdua questão metafísica, que Benjamin trata politicamente, isto é, analisando a marca do tempo pleno na história” (MATE, 2011, p. 357). É importante dizer que Benjamin aponta a política como um campo da luta no qual a utopia de uma sociedade sem classes se faz possível, o que acentua o caráter messiânico de uma nova política, por mais "destrutiva que seja" (BENJAMIN, apud MATE, 2011, p. 356).

No trabalho de interpretação das relações entre texto literário e mundo representado, a busca por uma ordem política ideal não desconhece as dificuldades a serem enfrentadas pela vontade transformadora e revolucionária, pois, conforme Reyes Mate (2011, p. 365), "a realidade, não obstante, segue outros roteiros". Em Os emigrantes, o papel revelador dos fatos singulares é crucial para entendermos as experiências individuais e seus impactos coletivos na configuração da memória representada por um narrador que funciona como articulador rigoroso do cronotopo romanesco. O narrador funciona ora como historiador ora como ficcionista e em ambos os casos ele é crítico da impossibilidade da história e da ficção darem conta da totalidade dos fatos. Entretanto, ele está sempre no encalço dessa totalidade, nem que seja como uma utopia precária que persegue, recorrendo à intercalação de vozes de testemunhas dos fatos e dos eventos que sua narrativa procura organizar.

Em uma passagem da quarta e última parte do romance, no momento em que o narrador esmiúça os fatos da vida de Max Aurach (parcialmente inspirados no artista plástico judeu Frank Auerbach), lemos:

Durante os meses de inverno de 1990/1991, no pouco tempo de que dispunha, portanto em geral nos chamados fins de semana e à noite, trabalhei na história aqui relatada de Max Aurach. Era um trabalho muito laborioso, que muitas vezes empacava no mesmo ponto durante horas ou dias, e não raro voltando atrás, quando eu era constantemente atormentado por escrúpulos cada vez mais perceptíveis, que me paralisavam cada vez mais. Esses escrúpulos provavelmente tinham a ver com o objeto de minha narrativa, a que eu pensava não conseguir fazer justiça, e com a precariedade 
da profissão do escritor. Eu cobrira centenas de páginas com rabiscos a lápis ou esferográfica. A maior parte disso tudo fora riscado, posto fora ou recoberto de acréscimos que quase o tornavam ilegível. Mesmo aquilo que finalmente salvei como forma "definitiva" me pareceu um fracasso. Portanto eu hesitava em enviar a Aurach a versão abreviada de sua vida, e enquanto ainda hesitava veio de Manchester a notícia de que Aurach fora internado no Washington Hospital com enfisema pulmonar.

Neste fragmento, percebemos que o relato da história frequentemente se transforma em história do relato, confirmando o desnudamento dos mecanismos textuais como característica potente do discurso literário. O relato de Aurach planta dúvidas em seu suposto biógrafo (o narrador/Sebald) quanto à eficácia da narração em dar conta de uma verdade sempre questionada pela ficção: por um lado, Sebald busca um diálogo com a história tentando extrair dela uma verdade; por outro, ao desnudar-se, aponta para os limites e alcances da busca encenada pelo texto, mas entende que é essa a potência da escrita: permitir que a dúvida se instale no relato e se torne matéria-prima do jogo ficcional que demanda um leitor-crítico que problematiza os grandes relatos históricos. No texto literário, e com Sebald não é diferente, desvelam-se tanto o caráter ideológico da escrita quanto da intervenção teórica.

Embora não seja o objeto de nossa investigação neste momento, ressaltamos que o espaço biográfico é repleto de nuances, desde a busca pela verossimilhança do que se narra até a desconfiança mais profunda na validade do dado documental pelo qual Sebald fixa uma determinada imagem da verdade no tempo-espaço do texto. Sua escrita se converte em reescrita incessante, conforme inferimos no relato do narrador. Seu trabalho com a escrita é homólogo ao da rasura: acrescenta-se, corta-se, mas, principalmente, a escrita visa a seleções e combinações que desvelam uma realidade ampla para o leitor, na medida em que ele desconfia da fidelidade dos textos, mesmo os pretensamente biográficos ou autobiográficos. $\mathrm{O}$ eu que se manifesta no fragmento anteriormente citado de Os emigrantes quer recuperar elementos do passado que ele vê como insuficientes para o êxito do relato biográfico. Podemos perceber que o eu-narrador fala mais de si e dos processos criativos do que do próprio biografado. Os leitores de Os emigrantes sabem que os relatos são amparados por imagens e documentos que o eu narrador arregimenta com a finalidade de sustentar o que conta, entretanto, a narrativa se revela insuficiente em dar coerência aos vestígios do passado em prol da verdade histórica. Os escrúpulos de que o narrador se cerca o leva à conclusão de 
que não fará justiça a seus biografados, pois é precária a atividade do escritor, o que nos leva à outra questão: qual seria então a validade deste trabalho do biógrafo/historiador, já que ele de antemão reconhece a impossibilidade de trazer de volta o passado, a não ser, conforme apontara Benjamin (1985, p. 224), por meio da visão materialista histórica, que entende a imagem do passado como algo quesó se manifesta em momento de perigo: “O perigo ameaça tanto a existência da tradição como os que a recebem", o que leva Benjamin à conclusão de que "o dom de despertar no passado as centelhas da esperança é privilégio exclusivo do historiador convencido de que também os mortos não estarão em segurança se o inimigo vencer. E esse inimigo não tem cessado de vencer".

Seguindo Benjamin, o ato de narrar a experiência dos mortos será sempre da ordem do impossível, já que a experiência não volta nem pode ser recriada, a não ser na precariedade da reminiscência, porém,por conta dessa precariedade, o escritor-historiador revela (-se) o (no) perigo de acordar os mortos. Os sujeitos vencidos de Sebald, uns quase anônimos e outros mais conhecidos, aos poucos revelam, em sua grandeza trágica, um determinado percurso histórico que marcou o século XX: nele, escamoteou-se a narrativa de vidas desperdiçadas de sujeitos que emigraram voluntariamente ou de forma traumática e de tantos outros engolidos pela catástrofe. Os personagens de Sebald são migrantes, viajantes ou párias, viventes e sobreviventes de uma era de assombros.

As personagens que tematizam a busca do passado histórico pelo narrador de Sebald são respectivamente: Dr. Henry Selwyn; Paul Bereyter; Ambros Adelwarth e Max Aurach. Cada uma delas protagoniza momentos do romance. A unidade da obra é dada pelo narrador, que dá sentido à busca pela verdade de cada uma das vidas recriadas e que participam de sua memória afetiva por meio de laços de parentesco ou por eventualmente terem cruzado sua vida. Elas, de algum modo, acabaram compondo uma espécie de mosaico de indivíduos destruídos. Lidas de forma independente, suas histórias ganham em importância quando comparadas, pois cada uma delas recria uma imagem do passado - ainda pensando em Benjamin - ou seja: são como reminiscências que nos chegam como um relampejo na noite escura da história.

Dr. Selwyn é alguém com quem o narrador deparaem fins de 1970, após assumir um cargo de professor na cidade de Norwich, na Inglaterra. Ele está à procura de uma casa nos arredores desta cidade para fixar residência e trava breve contato com Selwyn (entre 1970 e 1971), e a história deste encontro resulta na primeira parte do romance. O narrador traça um 
breve percurso da história da personagem, que remonta ao final de 1899, passando pelos anos 20 e 30 do século XX, quando a personagem chega a Londres, até seu suicídio em 1971. Alinha temporal se estende, conforme apontado anteriormente, até 1986 - quando o corpo do grande amigo de Selwyn, desaparecido nas geleiras de Oberaar em 1914, é descoberto. Neste percurso da memória, destaca-se ainda um episódio em que a família de Selwyn chega a Londres pensando ter aportado na América, no afã de abandonar o continente Europeu que, como a história confirmou, rumava à catástrofe. Após a Segunda Guerra, o que se lê é ainda uma narrativa de desencanto, que não se dissipou após a derrota dos fascismos:

Os anos da Segunda Guerra e as décadas subsequentes foram para mim um tempo sem sentido e ruim, sobre o qual, mesmo que quisesse, nada teria a contar. Quando em 1960 tive de fechar meu consultório e despachar meus clientes, desfiz os últimos contatos com o chamado mundo real. Desde então quase só falo com plantas e animais (SEBALD, 2002, p. 27).

A supracitada fala do Dr. Selwyn remete a uma relação intrínseca entre memória e esquecimento. $\mathrm{O}$ fato de o narrador tentar dar sentido a um passado traumático e estilhaçado talvez explique sua dificuldade em resgatar o tempo vividono presente e em sua plenitude. Selwyn também funciona na estrutura discursiva do romance como um narrador homodiegético - embora haja um primeiro narrador que controla os demais discursos e os protagonistas sejam sujeitos de quem ele diz saber algo, por ter convivido com eles de alguma forma ou porquese interessa em resgatar suas vidas através de depoimentos, imagens, relatos e documentos - que passa a ter voz, embora controlada, no relato. O narrador-personagem não esquece e nem quer que esqueçam essas vidas desperdiçadas, mas é consciente da inevitabilidade do esquecimento como parte do destino histórico dos homens.

Dentre as seminais interpretações sobre as relações entre memória e esquecimento, Michael Pollak (1989) - acerca dos trabalhos de Maurice Halbwachs e Pierre Nora - destaca os diversos pontos de referência que são indicadores empíricos da existência de uma memória coletiva: monumentos, estilos arquitetônicos, paisagens, tradições, costumes, folclore, música, culinária etc. Com o auxílio de Sebald, introduziremos a imagem na lista de Pollak. Podemos perceber o quanto a profusão de imagens disponibilizadas se torna um indicador potente de uma memória coletiva que se perpetua, especialmente no ciberespaço. Os lugares da memória, 
antigos e novos, não apenas reforçam sentimentos de pertencimento como apontam para diferentes esferas das fronteiras sociais e culturais de uma comunidade dada. Em um contexto histórico no qual o sentido de pertencimento ora se homogeniza ora se pulveriza, as personagens de Os emigrantes flertam com o esquecimento, seja por conta do trauma vivido, pela resistência em lembrar ou pelas estratégias de sobrevivência que buscam traçar. $\mathrm{O}$ cansaço da memória, paradoxalmente, é o que faz com que o Dr. Selwyn resista ao contato com o mundo real em favor do diálogo com plantas e animais -silêncio apenas rompido pelo narrador investigador, que resolve acordar os mortos e dar sentido a eles. Por outro lado, Selwyn aponta o silenciamento como espécie de fala concentrada, máximo do discurso ali representado pela mudez. Recorrendo ao antropólogo francês David Émile Durkheim, Pollak entende a memória coletiva como uma força quase institucional que reforça a coesão social, dando unidade, continuidade e estabilidade àquilo que seria representado pela nação e pela memória nacional. Isso significa que a memória coletiva não é apenas um dado negativo e impositivo da dominação ou violência simbólica (que nela coexistem, obviamente), mas teria ainda uma função positiva, de preservar uma forma talvez mais completa dos vestígios deixados por uma comunidade dada ao longo da história.

O narrador de Sebald se comporta como um detetive que investiga pistas deixadas nas trilhas da história, como na passagem em que quer revelar os meandros da vida de seu tio-avô Ambros Adelwarth e seu relacionamento com o herdeiro milionário Cosmo Solomon. $\mathrm{O}$ personagem-narrador está em Deauville, cidade no centro da Normandia, em meados de setembro de 1991, tentando encontrar "um resto de passado, alamedas verdes, passeios na praia ou um público mundano ou semimundano", fantasias logo desfeitas ao avistar a praia "de mar outrora lendária", agora "implacavelmente decadente, como qualquer lugar que se visite hoje, não importa em que parte do mundo ou em que país, arruinada pelo tráfego de carros, pelo comércio de butiques e pelo ímpeto destrutivo que cada vez se espalha mais" (SEBALD, 2002, p. 117). Insatisfeito com as parcas informações sobre a passagem de Ambros e Cosmo pelo local, o narrador se dedica a descrever o balneário, suas estruturas turísticas para estrangeiros, especialmente japoneses, os hotéis decadentes e o alarido na região outrora conhecida como a Meca de dândis, mundanos, párias e excluídos de todos os tipos. Em seu quarto de hotel, o narrador sonha que atravessa o Atlântico em um paquete que desembarca no Hotel Normandy, em setembro de 1913. No hotel, as imagens oníricas vêm em profusão: uma senhora emplumada fumando um charuto brasileiro; uma viagem de carruagem 
ao Hôtel Rochel Noires; flâneurs movendo-se sem direção fixa; hóspedes deitados em divãs e sofás na sala de leitura etc. Após dias e noites à procura de Cosmo e Ambros, o narrador os avista em imagens fugidias:em uma entrada do hotel, no elevador, dobrando uma esquina, tomando chá no pátio ou no saguão do hotel, folheando jornais trazidos pelo motorista Gabriel. Ao lembrar-se do sonho, o narrador faz importante revelação aos leitores:

Como em geral acontece com os mortos quando aparecem em nossos sonhos, eles estavam calados e pareciam um pouco tristes e abatidos. Aliás portavam-se como se seu estado alterado fosse um terrível segredo de família que jamais deveria ser revelado (SEBALD, 2002, p. 123).

Mais adiante, o segredo será mais bem compreendido pelos receptores:

De resto, lembrava eu agora, meus sonhos em Deauville foram repassados de um murmurar constante, vindo dos boatos que circulavam a respeito de Cosmo e Ambros. [...] E naturalmente a curiosidade cresceu, e as suposições ficaram tanto mais ousadas quanto mais os dois amigos se isolavam recusando convites que lhes eram enviados diariamente. Também a espantosa facilidade de Ambros para se expressar, em tão óbvio contraste com a natureza aparentemente muda de Cosmo, provocava toda a sorte de especulações (SEBALD, 2002, p. 124-125).

Nestes dois exemplos, pensando na visão do narrador sobre um passado recuperado pelo sonho em contraste com um presente no qual o progresso se mostra desastroso, a macro e a micro-história se imbricam, formando uma imagem dinâmica e bem acabada daqueles tempos melancólicos, previstos por Walter Benjamin quando tratou do mal do progresso e da melancolia como formas de constituição e compreensão históricas. Na história de Ambros e Cosmo, o interdito de sua relação secreta resgata para a narrativa a discussão sobre os dramas íntimos e as possibilidades de interpretação do exílio como forma de compreensão da história. As relações interpessoais expostas ao risco da clausura e da opressão são formas de se recuperar o eludido da história, revelando o que se deixou de contar, mas que permanece tatuado na pele, embora relegado pelos grandes relatos. Os mortos e os fantasmas pontuados pela narrativa de Sebald revelam sujeitos que precisam retornar ao campo semântico da 
narrativa oficial para demovê-la de sua ilusão de verdade. Eles chegam a um momento de perigo, como no relampejo benjaminiano que ilumina o presente e recupera o passado. Por sua condição social e econômica, Cosmo e Ambros podem circular de país em país, como se fossem exilados voluntários em périplo por um mundo em transformação, na primeira metade do século XX, como se para eles nenhuma ancoragem fosse desejável. Pertencer também pressupõe a possibilidade da migração sem pouso, o que revela em Os emigrantes, formas de resistência ao mal em um mundo alegorizado na solidão e mudez de Cosmo.

Ao percorrermos o texto de Sebald, identificamos intensas interseções entre paisagens, países, regimes políticos, histórias, culturas reveladas por uma narrativa de trânsitos. Esses percursos narrativos criam passagens entre a história individual, a memória coletiva, as subjetividades e as múltiplas formas de organização identitária observadas no cruzamento de fronteiras linguísticas, sociais, e religiosas, o que explica o porquê de Sebald situar seu narrador em uma espécie de lugar-limite, entre-lugar no qual o leitor também é lançado: confluência híbrida de discursos em que as imagens - propiciadas pela leitura ou pelos estímulos visuais das fotografias que cortam a narrativa - são estruturadas por um narrador com grande domínio do discurso, mas que concede voz (ainda que sob seu crivo) àqueles de quem fala. $\mathrm{O}$ fato de o narrador traduzir ou interpretar por meio do discurso o pensamento de suas personagens se deve, obviamente, a um dado empírico, de que todos estão mortos e o que se pode fazer diante deste silêncio é conceder voz aos sujeitos por uma dupla representação: política, ao "falar-por", "como se" fosse investido de um mandato que legitima a ficcionalização; e literária, quando o "falar-por" revela as estratégias discursivas de se conceder voz ao outro enquanto o discurso indireto livre descortina a estratégia ficcional, em que um enunciador primeiro finge ser o outro que enuncia.

Os processos de negociação estabelecidos pela narrativa tentam conciliar "a seletividade de toda memória", as "memórias coletivas" e as "memórias individuais" (POLLAK, 1989, p. 3). Sebald se coloca ao lado dos excluídos da história e nesse sentido o silêncio é uma forma de contraponto ao excesso de narrativas dos vencedores. Nesse recolhimento o silêncio grita e se torna o máximo de concentração das falas rasuradas. Talvez por isso, ao lado das imagens-despojos de um passado arruinado e dos documentos, as narrativas de Sebald são suplementadas pelos relatos orais, pela memória dos despossuídos, regatada através de um "ouvir dizer" que, longe de formar um conjunto lógico e sistemático de verdades solidificadas, insinua que um fato considerado perdido para a história se enche de 
significação quando trazido de volta ao presente, como o corpo soterrado nas geleiras de Oberaar, que retoma o curso da história ao reaparecer 72 anos depois.

$\mathrm{Na}$ terceira parte do romance, a intensa recuperação do passado de Ambros Adelwarth se inicia com a revelação de que restava quase nenhuma lembrança daquele homem com que o narrador cruzara somente uma vez, no distante ano de 1951, em uma breve visita de alguns dias dos parentes americanos à cidadezinha de W. A visita, entretanto, impactaria a vida da criança de então, principalmente por ter despertado nela o desejo de, assim como seu tio-avô, emigrar para a América (como se vê, a América é um elemento recorrente na imaginação dos personagens, representação da possibilidade de recomeço e libertação). A visita dos parentes emigrados que voltam da América provoca uma comparação entre o modo de vida americano e as contraditórias ações perpetradas pelas forças de ocupação no pós-guerra: "Eles estragavam as casas que confiscavam para morar, não tinham flores nas sacadas e em lugar de cortinas botavam nas janelas tela contra moscas" (SEBALD, 2002, p. 74).A reescrita da história efetuada por Sebald não nos deixa inertes quanto ao fato miúdo, corriqueiro, especialmente quando atua como o cronista benjaminiano, que não distingue a potência histórica da ocupação americana dos efeitos cotidianos que ela provoca e nem considera aqueles fragmentos de acontecimentos e experiências perdidos para a reflexão político-social. Sebald faz crítica política ampla, auxiliado por um narrador que não se deixa levar apenas pelas seduções do grande relato, mas principalmente sabe retirar dos elementos mais prosaicos e das aparentemente insignificantes criaturas um conteúdo abrangente que ajuda a reformar e reavaliar os discursos históricos. Neste sentido, o silêncio é revelador e necessário. Michael Pollak (1989, p. 5) mostra que o silêncio dos sobreviventes do campo de concentração, ao retornarem à Áustria ou à Alemanha, também se deveu à necessidade de convivência com aqueles que "de perto ou de longe, ao menos sob a forma de consentimento tácito, assistiram à sua deportação". Tal atitude revelava um "reflexo de proteção da minoria judaica" em relação à maioria da população e também dos próprios judeus que foram obrigados a compactuar com a máquina de extermínio e deportação nazista, além do próprio "sentimento de culpa que as próprias vítimas podem ter, oculto no fundo de si mesmas". Nesta linha de raciocínio, Pollak $(1989$, p. 5) concluirá que: 
O longo silêncio sobre o passado, longe de conduzir ao esquecimento, é a resistência que uma sociedade civil impotente opõe ao excesso de discursos oficiais. Ao mesmo tempo, ela transmite cuidadosamente as lembranças dissidentes nas redes familiares e de amizades, esperando a hora da verdade e da redistribuição das cartas políticas e ideológicas.

As narrativas de Os emigrantes se passam em localidades profundamente marcadas por guerras, sejam em pequenas cidades ou em metrópoles. O espaço geográfico se espalha por nações que receberam a massa de refugiados, especialmente durante a Segunda Guerra Mundial, como é o caso dos Estados Unidos ou da Inglaterra, países que foram uma espécie de Meca e bastião da resistência à expansão dos fascismos, para onde rumaram inúmeros sujeitos na esperança de um desfecho favorável a suas vidas ameaçadas. Não por acaso, os Estados Unidos serão representados como um espaço-receptáculo fértil para as memórias dos refugiados e sobreviventes, da mesma forma que a Inglaterra havia se tornado a pátria de inúmeros exilados, inclusive autoexilados como Sebald. Entretanto, essas memórias não podem ser lidas e interpretadas de forma retilínea já que, conforme Pollak (1989, p. 13), a recuperação destes discursos já se encontra contaminada pela "dificuldade colocada por esse trabalho de construção de uma coerência e de uma continuidade de sua própria história".

A leitura cerrada da ficção de Sebald, quanto mais se aprofunda nas relações entre o sentido e a recuperação da história pela memória, mais nos leva a uma aproximação com uma poética dos lugares por onde os sujeitos representados circularam e circulam. Seus discursos, proclamados através de uma fala verborrágica ou por meio de silenciamentos elegem a memória como campo privilegiado das tensões entre fala e silêncio, como nos mostra Pierre Nora (1993, p. 7):

A curiosidade pelos lugares onde a memória se cristaliza e se refugia está ligada a este momento particular de nossa história. Momento de conciliação onde a ruptura com o passado se confunde com o sentimento de uma memória esfacelada, mas onde o esfacelamento desperta ainda memória suficiente para que se possa colocar o problema de sua encarnação. $\mathrm{O}$ sentimento de continuidade torna-se residual aos locais. Há locais de memória porque não há mais meios de memória. 


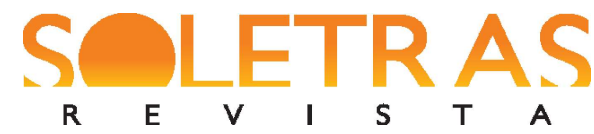

N. 38 - 2019.2 - PAULO CESAR SILVA DE OLIVEIRA

Se não há meios de memória, mas apenas locais onde ela residualmente perpetua o sentido de continuidade histórica das experiências perdidas, o ato de narrar passa a ser uma parceria entre a reminiscência e a escavação arqueológica, ambas promovidas por um escritoretnógrafo que circula pelos sítios arruinados do progresso e em busca de respostas que de antemão ele sabe que não encontrará. O leitor que se se sentir entediado ao percorrer as quase trinta páginas iniciais da quarta parte de Os emigrantes (em que há uma descrição minuciosa de lugares e eventos) caso consiga vencer o desafio da leitura verá que este adiamento e esta prolixidade estão a serviço da forma narrativa, cujos signos em profusão descortinam fatos da experiência que, embora inúmeros, não dão conta das múltiplas respostas às perguntas endereçadas ao passado. E se esse passado é traumático, a narrativa depara com a resistência dos sujeitos em relatar os acontecimentos dolorosos, visto que nos atos de fala acaba-se dando forma e sentido ao que se procurou recalcar, daí a dificuldade de trazer ao presente a memória da dor experimentada.

Ao mesmo tempo em que lê um artigo sobre Max Aurach em uma revista, o narrador de Os emigrantes contempla uma foto do pintor, concentrando-se no estudo "do olho escuro de Aurach" contemplando o vazio, o que o leva a compreender "tardiamente por que inibições e timidez naquele tempo" evitara "falar sobre a origem de Aurach" (SEBALD, 2003, p. 177 178). Quando Aurach ganha voz, relembra um período de sua vida e seu discurso passeia por reflexões filosóficas sobre o tempo, o passado e o futuro. São reminiscências entrecortadas por imagens fragmentadas que reconstroem uma Alemanha vista como um país "extraterritorial, atrasado, destruído, povoado por pessoas cujos rostos são ao mesmo tempo belíssimos e terríveis" (SEBALD, 2003, p. 181), onde os eventos que já pressupunham a catástrofe dos anos 1940 estão sintetizados no episódio da queima de livros na Praça do Paço em Würzburg, fato que antecedeu os expurgos, as perseguições e, posteriormente, culminou na chamada "solução final", que condenou milhões à morte.

Em relação aos sujeitos representados por Sebald, podemos dizer, concordando com Roney Cytrynowicz (apud SELIGMANN-SILVA, 2003, p. 125), que eles "sentem uma espécie de solidão insuperável, como se a memória constituísse um peso terrível do qual jamais se está livre, mas que é, ao mesmo tempo, o único registro seguro e confiável". Por conseguinte, o fenômeno manifesto em sua narrativa se apresenta como aparição, um fantasma que ronda a história e a assombra, abalando suas estruturas nelas inserindo uma memória espectral. A epígrafe que abre a quarta e ultima parte do romance de Os emigrantes 
(SEBALD, 2002, p. 147) sugere que há um mundo de sombras por onde as criaturas de papel ficcionalizadas se movem: "Eles vêm ao anoitecer e procuram a vida". Esta vida nem sempre é encontrada nos fatos cotidianos ou na experiência dos sujeitos trazidos àluz pela narrativa de Sebald, mas ela pode ser vislumbrada nos sonhos, delírios e imagens fantasmagóricas de um tempo de neblina e sombras, no mundo arruinado que é o lugar por onde nos esgueiramos, tentando sobreviver com o mínimo de esperança de que nossa humanidade encontrará meios de sobreviver às catástrofes e de derrotar a barbárie.

Para voltarmos aos "lugares onde a memória se cristaliza", como diz Pierre Nora, uma passagem de Os emigrantes nos ajuda a pensar em um desfecho provisório para esta breve reflexão. Mesmo esfacelada, a memória, ainda que de forma precária, consegue encarnar em alguns lugares, trazendo ao presente uma verdade histórica provisória, somente possível porque vislumbramos o relampejo em momento de perigo, como imaginou Walter Benjamin. Nesses breves momentos, a representação do real encontra na arte um forte aliado, capaz de fixar imagens e agrupar os resíduos dispersos da memória em relatos plenos de experiências fantasmáticas, porém humanas, que somente a ficção, porque sabe de algo sobre as coisas, consegue realizar. A ficção não quer definir ou amarrar a vida e os fatos e isso é algo que Sebald magistral e poeticamente registrou, como mostra a passagem de Os emigrantes, que serve de conclusão provisória a esta reflexão:

Os instrumentistas eram quatro jovens um pouco envelhecidos e com cabelo crespo. Tocavam canções dos anos sessenta que eu ouvira não sei quantas vezes no Union Bar em Manchester. It is the evening of the day. A vocalista, uma mocinha loura com voz ainda muito infantil, soprava devotamente no microfone que segurava com as duas mãos bem junto à boca. Cantava em inglês, mas com nítido sotaque francês. It is the evening of the day, I sit and watch the children play. Às vezes, quando não conseguia lembrar direito as palavras, cantarolava lindamente. Senti-me em uma das poltronas revestidas de esmalte branco. A música enchia o aposento. Nuvens rosadas até o teto com guirlandas douradas. Procol Harum. A whiter shade of pale. Pura sentimentalidade (Grifos do autor). 


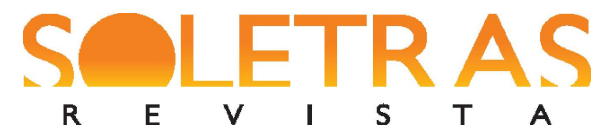

N. 38 - 2019.2 - PAULO CESAR SILVA DE OLIVEIRA

\section{Referências}

. Fragmento teológico-político. Flanagens, 06 de agosto de 2007. Disponível em: http://flanagens.blogspot.com/2007/08/fragmento-teolgico-poltico.html. Acesso em $11 \mathrm{de}$ fevereiro de 2019.

; O Eu e O livro do desassossego. In: ; OLIVEIRA, Paulo César S. Uma literatura inquieta: memória, ficção, mercado, ética. Rio de Janeiro: Caetés; CNPq; FAPERJ, 2016, p. 57-72.

BAUMAN, Zygmunt. Modernidade líquida. Trad. Plinio Dentzien. Rio de Janeiro: Jorge Zahar, 2001.

BENJAMIN, Walter. Sobre o conceito de história. In: - Magia e técnica, arte e política: obras escolhidas, v. I. Trad. Sergio Paulo Rouanet. 4. ed. São Paulo: Brasiliense, 1985, p. $222-232$.

CUESTA, Micaela. Fragmento teológico-político de Walter Benjamin: una interpretación. Buenos Aires, Universidade de Buenos Aires, s/d, p. 59-74. Disponível em: http://uba.academia.edu/MicaelaCuesta. Acesso em 22 de fevereiro de 2019.

CYTRYNOWICZ, Roney. O silêncio do sobrevivente: diálogo e rupturas entre memória e história do Holocausto. In: SELIGMANN-SILVA, Márcio. História, memória literatura: o testemunho na era das catástrofes. Campinas, SP: Editora da Unicamp, 2003, p. 138.

FUNARI, Pedro Paulo A. Considerações em torno das "Teses sobre a filosofia da história", de Walter Benjamin. Revista Crítica Marxista, Unicamp, Campinas, SP, n. 3, 1996, p. 45-53. Disponível em www.ifch.unicamp.br/criticamarxista/arquivos biblioteca/artigo17Art1.3.pdf. Acesso em 12 de janeiro de 2019.

GAGNEBIN, Jeanne Marie. Walter Benjamin: os cacos da história. Trad. Sonia Salzstein. 2. ed. São Paulo: n-1 Edições, 2018.

HELENA, Lucia. Náufragos da esperança: a literatura na época da incerteza. Rio de Janeiro: Oficina Raquel, 2012.

MATE, Reyes. Meia-noite na história: comentários às teses de Walter Benjamin "Sobre o conceito de história”. Trad. Nélio Schneider. São Leopoldo, RS: Ed. Unisinos, 2011.

NORA, Pierre. Entre a memória e a história: a problemática dos lugares. Projeto História, Pontifícia Universidade Católica de São Paulo, São Paulo, n. 10, dez. 1993, p. 7-28.

OLIVEIRA, Paulo César S. Uma literatura inquieta: memória, ficção, mercado, ética. Rio de Janeiro: Caetés; CNPq; FAPERJ, 2016, p. 57-72.

POLLAK, Michael. Memória, esquecimento, silêncio. Estudos Históricos, Rio de Janeiro, v. 2, n. 3, 1989, p. 3-15. 


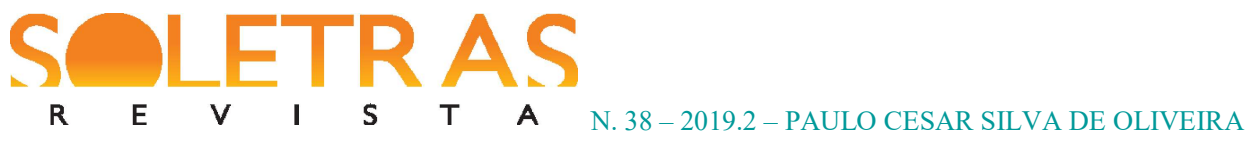

SANTOS, Boaventura de Sousa. A queda do Angelus Novus: o fim da equação moderna entre raízes e opções. In: . A gramática do tempo: para uma nova cultura politica. 3. ed. São Paulo: Cortez, 2010, p. 51-92.

SANTOS, Milton. Por uma outra globalização: do pensamento único à consciência universal. 9. ed. Rio de Janeiro; São Paulo: Record, 2002.

SEBALD, W. G. Os emigrantes. Trad. Lya Luft. Rio de Janeiro; São Paulo: Record, 2002.

SELIGMANN-SILVA, Márcio. História, memória literatura: o testemunho na era das catástrofes. Campinas, SP: Editora da Unicamp, 2003.

\title{
Wanderers, different, unequals: on The emigrants, by W. G. Sebald
}

\begin{abstract}
This paper proposes a critical reading of The emigrants, by W. G. Sebald (2002), a fiction that problematizes the dichotomies established in modernity between a promise of mobility as opposed to the closure in a world marked, according to Walter Benjamin, by the "evil of progress", inscribed in the nightmare of history. Sebald's fiction builds on the intersections between memory, document, history, ethnography and fiction. His text will be read as a movement of passage that summons criticism to analyze a series of discourses that compose a reflexive field around the antinomies of a modern Europe that would be ravished in the twentieth century by trauma, catastrophe and ruin. In this sense, Sebald dialogues with hybrid textual forms that contribute, through a fragmented narrative, to the renewal of literary realism, influencing contemporary fictional prose. In Sebald's works the ruined world becomes a kind of allegory of the age of catastrophes. The article discusses the theoretical implications and the scope of this set of themes and reflections.
\end{abstract}

Keywords: Contemporary fiction. History. Memory. Trauma. Realism. Criticism.

Recebido em: 07 de junho de 2019.

Aceito em: 07 de julho de 2019. 